\title{
Innovative Development of Public Policy on Food Security in the Period of the Covid-19 Pandemia
}

\author{
Larysa Hromozdova ${ }^{1^{*}}$, Oleksandr Yerankin $^{2}$, Nadiia Pysarenko $^{3}$, Antonina Artemenko ${ }^{4}$, \\ Viktor Maliarevskyi ${ }^{1}$, Yana Dovhenko ${ }^{5}$ and Fato Sharoian ${ }^{67}$ \\ ${ }^{1}$ Kyiv National Economic University named after Vadim Hetman, Department of Regions and \\ Tourism, 03057, Victory Avenue, 54/1, Kyiv, Ukraine \\ ${ }^{2}$ Kyiv National Economic University named after Vadim Hetman, Department of Marketing, 03057, \\ Victory Avenue, 54/1, Kyiv, Ukraine \\ ${ }^{3}$ Capital Union School, 03039, str. Keramichnyi 7-A, Kyiv, Ukraine \\ ${ }^{4}$ Kyiv National Economic University named after Vadim Hetman, Department of Foreign of \\ Marketing Faculty, 03057, Victory Avenue, 54/1, Kyiv, Ukraine \\ ${ }^{5}$ Central Ukrainian State Pedagogical University named after Volodymyr Vynnychenko, Departments \\ of Applied Mathematics, Statistics and Economics, 25000, str. Shevshenko 1, Kropyvnytsky, Ukraine \\ ${ }^{6}$ Taras Shevchenko National University of Kyiv, 01033, str Volodymyrska 64/13, Kyiv, Ukraine \\ ${ }^{7}$ National Bank of Italy, Via Nazionale str., 91, Rome, Italy
}

\begin{abstract}
The purpose of the article is to analyze the prospects for innovative development of public policy in the sphere of food security and to develop practical recommendations regarding the use of cultivated and wild plants in the sphere of food supply to improve the population's immunity during the pandemic. The article analyzes the impact of the COVID19 pandemic on the reformatting of public food security policy. The destruction of traditional food stereotypes of the population certainly took place. The emergence and development of innovations in the sphere of nutrition of Ukrainian citizens are considered. The tendency to increase the nutritional value of wild plants has been determined. Such plants are used to improve the immunity of the population and overcome the problem of lack of usefulness of food. The main barriers and problems of changing food stereotypes of the population and food policy of public authorities are substantiated. It is established that there is an insufficient level of support of public authorities in modern conditions of the development of the newest gathering in the sphere of food security in Ukraine. It has been revealed that the cost of manufacturing food products is relatively low in the modern world. However, the nutritional value and benefit to human health are minimal. There is a tendency to increase the number of diseases caused by the use of low-quality products. Alternative solutions to this urgent problem are considered. The influence of natural food additives and a return to the natural way of eating are investigated.
\end{abstract}

\footnotetext{
* Corresponding author: gromozdovag@gmail.com
} 
The public authorities' importance of a broad information campaign regarding the dissemination of information to the public and food safety has been proven. As a result of the emergence of a pandemic, the public authorities must follow clear, consistent measures to improve the situation that has developed. It is definite that in addition to economic measures, attention should be paid to psychological measures aimed at changing the behaviour of the population. The necessity of destroying the industrial food traditions of the population was substantiated. The importance of actualization of the process of implementation of ecological food innovations was found out. Awareness of growing wild and gathering for food takes a prominent place. Ukraine has excellent opportunities for development in these areas. Reforming the state food security in today's conditions is necessary to preserve the health of the nation. The need to strengthen the role of public authorities in creating favourable conditions for environmentally sound use of food potential of wild-growing plants has been noted. Keywords: food, food policy of public authorities, wild-growing plants, reforming the food security system, food traditions and innovations, the newest gathering.

\section{Introduction}

The problem of food security in modern Ukraine has never lost its relevance. Recently, in conditions of relative prosperity, many citizens with excessive body weight have appeared. This is caused by overeating. It turned out that successes in combating manifest hunger provoked a new problem - "hidden hunger. Even a small number of calories in the food is accompanied by a lack of essential nutrients, microelements. Another danger was the contamination of food with a wide range of toxicants that enter due to general environmental pollution, chemicalization of agriculture, processing and food industries. It turned out that a decrease in its quality accompanies an increase in the quantity of food production.

However, the pandemic has threatened the quality and quantity of food supplies population. Risks of hidden and obvious hunger have increased. The economic crisis caused by quarantine measures contributes to reducing food production and the income of the population. Food is economically less accessible to consumers. This is especially true for high-quality, organic foods. High prices characterize such products. Therefore, the continuation of food traditions is unproductive. We need to rethink food traditions and find food innovations that will be relevant in the new reality.

\section{Literature review}

The pandemic phenomenon caused by the COVID - 19 coronavirus is being actively discussed in scientific circles. Such discussion is beneficial not only from the medical aspect but also from the economic, political, philosophical, social, psychological and other perspectives. In particular, the political perspective of solving social problems generated by the pandemic is devoted to the scientific reconnaissance of V.P. Bocharnikov, O.Y. Grynevich, I. Lazaridou, I.G. Markovich, S.V. Sveshnikova, A. Ostroushko, O.V. Polyakova, M. Stabulis and others. 
Most studies cursorily note that the fight against the pandemic one of the negative consequences will be aggravation of the food problem in all countries of the world (K. Zubkova, I. Koval, O. Stoyanova). However, a unique analysis of the problems of aggravation of the food problem in the pandemic and the post-pandemic era is still lacking in the scientific literature. There is almost no discussion of the direction of the public policy of revising the food traditions of the past era. Not enough attention has been paid to the introduction of innovations in food production, trade and consumption.

Most experts note (E. Bragina, A. Gerasimenko, V.I. Kostra, T.V. Burlay) that there will be no return to the past in the post-consumer era. The life of mankind will change significantly. This means that changes will also take place in the sphere of nutrition.

Significant attention to the problem of reforming state food security in the context of traditional influences of the twentieth century is given in the works of T.G. Vasiltsiv, V.V. Boyko, O.I. Kutz, O.V. Bokiy, L.C. Kupinets. One of the postulates of this approach was the focus on the use of agricultural products in nutrition. Products that were obtained from cultivated plants. Repeatedly expressed the idea of the high health and economic potential of gathering and food use of wild-growing flora (G. Bergson, A. Kashcheyev, A. Ursul). The potential of wild-growing flora remained almost unrealized.

At present, under the influence of the COVID - 19 pandemic, a rethinking of the world economy is rapidly taking place (V. Galasyuk, O.J. Grynevich, I.G. Markovich, M. Stabulis, I. Lazaridou, A. Ostroushko). Rethinking social consciousness, the formation of new realities (A. Gerasimenko, V.I. Kostra, T.V. Burlay). Consider innovative shifts in food stereotypes that need support from public policy bodies (K. Zubkova, O. Stoyanova, I. Koval) to ensure food security during the COVID pandemic, - 19. However, for the time being, the analysis of problems that hinder the use of the food potential of wild flora of Ukraine remains behind the attention. Such analysis is needed to solve the problems of food security during the pandemic.

The purpose of the article is to analyze the prospects for innovative development of public policy in the sphere of food security and to develop practical recommendations regarding the use of cultivated and wild plants in the sphere of food supply to improve the immunity of the population during the pandemic.

\section{Results}

Analyzing the problems of correcting food traditions and the formation of innovations at the public level, we will operate with the concept of "public policy" and "public administration". These terms are meaningfully broader in comparison with the recently popular terms "government policy" and "government administration" [14, p. 108]. This conceptualization takes into account the increasing role in the political process of non-state formations (local self-government, various institutions of civil society, non-state organizations, associations of citizens, private structures and agencies, etc.) that fulfill the role of partners.

The concept of "public policy" focuses on the fact that the policy of public administration bodies should not be directive, as it was thought before. Public policy should be based on the mechanisms of public coordination of the interests of stakeholders and aimed at achieving socially significant goals and social partnership in solving socially important tasks. Attention is drawn to the characteristic for the XXI century interaction of civil society and the state in solving those or other public problems. This position is a counterbalance to the diktat of state power, which was usual for the mentality of the twentieth and earlier historical stages of state creation.

Currently, the policy in the sphere of any, including food security, according to the new worldview is not imposed on society. The policy is implemented both through society and through state institutions of public authority. Trying to achieve the effect of the assemblage 
and readiness of society to the challenges, the state now uses modern methods of shaping public opinion. Under such conditions, public policy, regulated by democratic procedures, legitimizes public opinion. Public policy creates a counterpart in the person of the public, which is ready for dialogue and taking responsibility for compatible decisions in different spheres and, in particular, in the sphere of food security.

Scientists define the content of the concept of "food security" in different ways. Most often it is considered the ability of public authorities at the national level to guarantee selfsufficiency in basic products in amounts necessary to meet the food needs of the population and in a sufficiently diverse range, as well as the quality of food at a level that ensures the performance and health of citizens. No less difficult task of public administration than ensuring the physical availability of food is to create conditions for their economic accessibility. Otherwise, physical sufficiency, or even a surplus of food, will not protect more than a smaller part of the population from hunger [3, p. 132; 11, p. 265].

In addition to the physical and economic accessibility of food, it is advisable to highlight their cognitive accessibility. There are a large number of foods that are physically and economically accessible to citizens. But completely fall outside the food sphere through a system of cognitive gaps, cognitive barriers and food distortions of this individual, social group or society as a whole.

For example, exceptionally accessible in all attitudes are nettle, glague, dandelion, pigweed, purslane, amaranth and many other wild plants. However, for various reasons that are caused by socio-cultural factors, people do not perceive these very useful foods for food and even consider them forbidden [8, p. 7]. Therefore, the task of public authorities is not only to ensure the physical and economic availability of food to citizens. Public authorities must provide informative and cognitive information to the population about the usefulness of consumption.

Thus, a feature of public policy in the sphere of food supply of citizens is the expansion of nutritional competence of citizens. Dissemination of information on the use of the spectrum of cultivated plants and encouraging more people to consume currently little used plants (topinambur, turnips, borago). Supplement the food ration with wild plants (amaranth, pigweed, nettle, purslane, bluegrass, dandelion, elderberry, hawthorn, blackthorn, rowanberry ash).

The peculiarity of modern man's nutrition is that most of the dishes she consumes are not made as a result of home production, and is a product provided by the food industry in the form of finished products or various kinds of semi-finished products and the like [2, p. 50]. That is, about $50-55 \%$ of agricultural production is used in processed form, $20 \%$ is used in agriculture itself and only $25 \%$ is consumed fresh [6, p. 45]. At the same time, the expressive trend is that the fate of processed products is rapidly growing. Against this background, the issue of compliance with the quality and environmental safety of food is sharpened.

As L.E. Kupinets notes: "Identification of quality indicators of food and agricultural raw materials to the indicators of current standards usually indicates a decrease in the nutritional value of products and exceeds the maximum acceptable standards for the capacity of harmful substances in it, which does not give grounds to classify agricultural products as safe. After all, having achieved an increase in the quantity of food, most countries have lost considerably in its quality. Biochemical diversity of nutrition has been lost through a reduction in the biodiversity of crops and animal breeds. Modern studies in the field of food safety indicate that the processing receives raw materials of plant and animal origin with reduced indicators of usefulness" [5, p. 26]. Industrial processing of agricultural raw materials very often through intensive thermal, chemical and other influences reduces the impoverished presence of its useful substances.

In today's context, scientists conclude that almost 2 billion people in the world today suffer from "hidden hunger. Such a number is almost one-third of the world's population and 
has numerous negative health consequences. That is, the prevalence of "hidden" hunger and real hunger and malnutrition are of comparable proportions [12 p. 86]. One approach to eliminating nutrient deficiencies is to provide urgent assistance to vulnerable groups through pharmaceutical supplements. Globally, the consumption of vitamins, minerals and dietary supplements continues to grow. The U.S., EU, China, India, and Japan have the fastest growing markets for dietary supplements. Consumers in these countries are becoming increasingly interested in maintaining their health, increasing their ability to work, and decreasing the amount of time they spend on sick leave. Increasing drug costs are also contributing to this conclusion.

The second approach is to increase the micronutrient intake of the population through food fortification. After World War II, food fortification became common in the United States and some European countries. The advantages of food enrichment with simultaneous improvement of nutrition consist in the fact that traditionally consumed foods can be enriched without the need to change the behavior of food consumers, and the costs of enrichment are compared to lower [9, p. 112].

A third approach regarding overcoming "hidden" hunger through dietary diversity with a combination of bio-enrichment of staple food crops. This was made possible with the use of bio-enrichment through the development of new varieties of basic food crops with an increased content of nutrients. Bio-enrichment is a cheaper process than compensating nutrient deficiencies with food additives or enriching products during processing. Therefore, the introduction of bio-enriched products into the food system is very promising. Lack of dietary diversity is the main reason why most of the world's population does not suffer from micronutrient deficiencies in the diet.

In contrast to the problem of real, hidden hunger and malnutrition, there is the problem of overeating. This problem causes overweight and obesity. Obesity is a major cause of diabetes and cardiovascular disease and other illnesses. At the same time, much of the responsibility lies with food producers, who continue to produce products with high sugar and fat content, as well as abuse the addition of various flavor enhancers to food to increase sales and make super-profits [10, c. 43]. This situation is due to the fact that the interests of producers do not coincide with the interests of society. Therefore, in many Western countries with the support of the state began measures to reduce sugar, calories, fats in food products. To companies that do not comply with these measures, taxes and fines are applied. But in Ukraine, a large number of food safety indicators are not regulated and not controlled. At the same time consumption of low-quality food products is promoted not only by low solvency, but also by insufficiently high cultural level of the population.

In political terms, the issues of food safety, nutrition and food security are inextricably linked. Dangerous food causes disease and malnutrition, which particularly affects newborns and infants, the elderly and the sick. Disease of food origin is an obstacle to the economic development of the state. Because they put a strain on the health system and seriously harm the national economy, tourism, trade, etc. If we take into account the fact that nowadays food supplies are international, food safety has another global dimension [15, p. 22]. Therefore, it requires effective cooperation between national governments, producers, and consumers of food products to ensure food safety.

In addition, the issue of food safety has not only a global and national aspect, but also a personal one. Responsibility in the choice of products and the composition of one's own diet is the key to preserving health and preventing a whole range of diseases related to the way of eating. It depends on citizens [16, p. 122]. The population chooses food products, reckoning with the advertising of producers. The choice of products for consumption also formulates the request regarding the development of the food industry.

Lack of biologically valuable food, violations of its regime cause significant harm to human health, reduce physical and mental performance, increase the risk of disease, 
occupational injuries, nervous and emotional stress, increase the impact of harmful factors of production and radiation and reduce the period of active life.

It should be noted that as a result of coronavirus epidemic problems of food security and health of the nation become more acute. Due to the application of various quarantine measures, which limit the economic activity of agricultural enterprises, transport movement of food products, the work of some markets of rural products and public catering institutions give rise to risks in the quality and quantity of food consumption [13, c. 97].

During the deployment of the first wave of the pandemic over 5 million people were forced to go on leave after quarantine [4 p. 2]. Small and medium-sized business owners lost $25-50 \%$ of their revenues, causing $10-25 \%$ of employees to be laid off. Even large businesses lost $10-25 \%$ of profits and plan to downsize by $25 \%$ [7, p. 48]. Under the conditions of a sharp drop in income the population is forced to save even more and reduce spending, including on food, and switch from higher-quality to lower-quality food products, even more in violation of the balance of the food structure. For the most consumed food products in Ukraine (bread, sugar, oil, vegetables), which are characterized by inelastic demand. Meat and meat products, as well as milk and dairy products are characterized by high elasticity. The decrease in income of the population will lead to a decrease in consumption. This will lead to the transition of products with high elasticity to a cheaper group of consumption.

Taking into account the noted circumstances caused by the coronovirus, which will obviously become a permanent reality in the coming years, the President's advisor announced the creation of a special operative coordination council on food security under the working title "Harvest 2020". The council should work to stay ahead of possible threats to the food supply of the population. Because, through the decrease of immunity of the population can increase the loss of population from coronavirus disease. After all, declining food quality causes public health to deteriorate. First of all it concerns the immune system of the population, which already has an increased load as a result of other unfavorable factors, : environment, bad habits, stresses, infectious agents and the like. Therefore, with quantitative and qualitative nutritional deficiencies, a weakened immune system accounts for a high level of infectious and noninfectious morbidity.

Thus, in the context of a pandemic, the already acute problem of healthy nutrition is repeatedly exacerbated. However, practice expressively shows that it is not enough for public authorities to achieve success in ensuring the availability and economic accessibility of quality food. In addition to the presence of economic opportunities to purchase it is necessary psychological readiness of citizens to make a choice in the direction of a healthy diet. Also the prevalence of various eating disorders and destructive food stereotypes is growing among Ukrainians. In the sphere of food there is quite a wide range of untapped resources.It is wildly growing raw materials, the consumption of which is promoted by the ignorance of the population and the presence of a number of psychological barriers, which have deep cultural and historical roots. Overcoming this kind of psychological barriers to the food use of wild plants could help to solve the problem of food security in the fields of modern Ukraine.

In many scientific studies it was found that in wild-growing plants the spectrum and concentration of substances necessary for the human body is much higher than in cultivated plants, which were bred by breeding from wild-growing ancestors. It was found that the noted losses in the amount of nutrients and usefulness are the greater the further the process of cultivation of plants and animals has gone [17, p. 433].

The negative impact of industrialized agriculture on the nutritional quality of cultivated plants and animals has been established. Because many vegetables and fruits as a result of soil depletion over the past 30 years have reduced the content of useful substances by more than half. In addition, as a result of the use of agrochemicals, cultivated plants have acquired in their composition a high number of harmful substances, which were not in the preindustrial agrarian era in the products of organic farming. 
It turned out that the agrarian domestication of nature and the emergence and development of the food industry creates food for humans in larger quantities than wildlife, but its quality becomes worse. The greater the amount of food, the worse its utility. That is, the transformation of wildlife into cultivated nature confirms the validity of Barry Kommoner's ecological law. The law notes that nature knows better, including in the area of creating adequate food for humans. Because of this scientific view of ecological and food problems, history and modernity have had the idea of reviving elements of the appropriation economy on a new basis. Such an approach was called the newest gathering [18 p. 4].

The newest gathering is understood not just as a revival of old gathering practices, but as a search for such forms of interaction between nature and modern society, where natural factors in their wild form are maximally involved in social activity. From this point of view it is the maximum use by the modern man of the gifts of wild nature in ecologically acceptable limits, the productivity of which is significantly underestimated in comparison with the production approach. This is a very promising direction of state stimulation of effective nature management, which needs preservation and expansion in the structure of the territory of the state of a part of the wild nature, part of which should be maintained absolutely reserved, and part of which should be set aside for the needs of the newest gathering.

Potentially the newest gathering can turn into a full-fledged sector of the economy. This implies a radical reform of the sphere of state administration towards the formation of the value status of wild nature in comparison to cultivated nature and the technosphere. The idea of the newest gathering can provoke the allotment of at least one third of the country's land area for wildlife. Also the ecologization of significant areas of the agrosphere, which will make it possible to harvest and use in nutrition a significant biomass of plants, which are currently neglected to qualify as weeds.

That is, in the conditions of modern Ukraine collecting can complement the agroproduction. The newest gathering can be carried out territorially within a certain rural area (unused in the agricultural sphere of wild or at least semi-wild nature in the form of meadows, plantation forests, joists, gullies). Or grow wild plants in gardens and orchards. However, people call these plants weeds. Such weeds are actually valuable food and medicinal plants (pigweed, amaranth, purslane, quickweed). However, the revival of gathering to the level of an economic industry is not possible at present without the support of the state.

\section{Conclusions and suggestions}

The increase in the volume of food turned into a sharp impoverishment of the concentration of useful components in food and the emergence of a number of harmful substances. The new challenges of the post-industrial era have increased the search for artificial high-tech foodstuffs. And this is an increase in trends toward a return on a new basis to eating natural products, organic farming, and the use of forgotten wild plants in nutrition.

A particularly important task of public food policy in the new conditions is the removal of psychological barriers to the food use of wild plants. The usefulness of which has been proven by ancient folk experience and the latest numerous scientific studies. However, the refutation of traditional stereotypes of industrial food is very powerful. Therefore, the social stress created by the COVID pandemic has, in addition to the obvious risks, a positive consequence in the destruction of food traditions and the acceleration of the process of ecological food innovation. Among the innovations, the revival of public trust in wild plants and gathering is a significant one.

The prospects for further research is to develop ways of informational support of public authorities to ensure the availability of wild plants to the population of Ukraine and the normative-legal regulation of the rational latest collection. 


\section{References}

1. Zakon Ukrainy «Pro osnovni pryntsypy ta vymohy do bezpechnosti ta yakosti kharchovykh produktiv» vid 23 hrudnia 1997 roku № 771/97-BP. Vidomosti Verkhovnoi Rady Ukrainy (BBP), 19, ст. 98 (1998)

2. H. Berson, Hydromeyoyzdat, 72 (1991)

3. T. Vasyltsiv, Stratehichna panorama, 2, 132-138 (2017)

4. V. Halasiuk, Ekonomika Ukrainy: pandemiia COVID-19, nova ekonomichna realnist, rekomendatsii. Ukrainian association the club of Rome. URL: http://www.clubofrome. org.ua/wp-content/uploads/2020/04/ DoslidzhennyaFond-Zajdelya.pdf.

5. A. Herasymenko, Visnyk Kyivskoho natsionalnoho torhovelno- ekonomichnoho universytetu, 3, 5-26 (2020)

6. O. Hrynevych, Ukrainskyi medychnyi chasopys, 3, 45-48 (2013)

7. K. Zubkova, O. Stoianova, I. Koval, Zbirnyk naukovykh prats $\Lambda^{\prime} \mathrm{OHO} \Sigma$, 48-49 (2020)

8. V. Kostrytsia, Ekonomika i prohnozuvannia, 1, 7-34 (2019)

9. A. Koshcheev, Pyshchevaia prombshlennost. 258 (1981)

10. L. Kupinets. Ekonomika kharchovoi promyslovosti, 1, 43-50 (2009)

11. O. Kuts, Prodovolchi resursy, 14, 262-276 (2020)

12. L. Malakhova. Visnyk Kharkivskoho natsionalnoho universytetu imeni V.N. Karazina. Seriia: Mizhnarodni vidnosyny. Ekonomika. Krainoznavstvo. Turyzm. 1086(2), 8-89 (2013)

13. A. Ostroushko. Kreatyvnyi prostir. 1, 97-98 (2021)

14. O. Pukhkal. Investytsii: praktyka ta dosvid. № 24, 106-112 (2017)

15. S. Svieshnikov. Zbirnyk naukovykh prats Tsentru voienno-stratehichnykh doslidzhen Natsionalnoho universytetu oborony Ukrainy imeni Ivana Cherniakhovskoho. 2, 22 29 (2020)

16. Zh. Sokolova. Эkonomyka, trud, upravlenye v selskom khoziaistve. 4, 122-132 (2019)

17. M. Stabulis. Zhurnal yevropeiskoi ekonomiky. T. 19, 3, 433-447 (2020)

18. A. Ursul . Khymyia y zhyzn. 11, 4-7 (1989)

19. Coronavirus: four out of five people`s jobs hit by pandemic. BBC news. 7, April (2020). URL: https://www.bbc.com/news/ business-52199888.

20. El-Erian M.A. Navigation the new normal in industrial countries (Washington, Per Jacobsson Foundation, 2010). URL: http:// www.perjacobsson.org/lectures/101010. pdf. 